\title{
Immigrants Comprise 31 Percent of Workers in New York State Essential Businesses and 70 Percent of the State's Undocumented Labor Force Works in Essential Businesses
}

Center for Migration Studies of New York (CMS)*

This paper provides estimates on "essential" immigrant (foreign-born) workers in New York State. These workers play a central role in safeguarding and sustaining state residents during the COVID-19 pandemic, often at great risk to their health and that of their families. Based on estimates drawn from 2018 US Census data, the Center for Migration Studies (CMS) estimates that 1.8 million immigrants work in jobs in the "essential businesses" identified by New York State (New York State 2020). These businesses fall into 10 categories (Appendix A) that meet the health, infrastructure, manufacturing, service, food, safety, and other needs of state residents. The majority of the New York foreign-born essential workers - 1.04 million - are naturalized citizens, 458,400 are legal noncitizens (mostly lawful permanent residents or LPRs), and 342,100 are undocumented.1

\section{Top-line findings}

CMS finds that two-thirds (66 percent) of the state's immigrant workers - those in the labor force aged 16 and over - work in essential businesses, compared to 56 percent of the native-born labor force. Foreign-born workers comprise 31 percent of workers in essential businesses, despite representing 28 percent of the state's labor force. A remarkable 70 percent of the undocumented labor force consists of essential workers. In particular, immigrants comprise:

- About one-third of health care sector workers in the state.

- Two-thirds (66 percent) of home health care workers and aides for the elderly; undocumented immigrants comprise 11 percent of all home health care workers and elderly aides in the state, and 6 percent of all workers in essential businesses.

- 23 percent of workers in medical equipment manufacturing and 30 percent in pharmaceuticals manufacturing; i.e., businesses that supply the health care sector.

\footnotetext{
*This report was authored by Mike Nicholson and Daniela Alulema, with substantial contributions from Robert Warren and Donald Kerwin. It was published on April 23, 2020 and updated on April 30, 2020.

${ }_{1}$ CMS's undocumented estimates include two legally present populations, Deferred Action for Childhood Arrivals (DACA) and Temporary Protected Status (TPS) recipients.
} 
- 41 percent of janitors and building cleaners, 33 percent of workers in disinfection, and 38 percent of those who manufacture soap and cleaning compounds,2 all crucial functions in responding to the pandemic.

- 47 percent of the state's transportation industry (excluding airlines), including buses, rails, and vehicles-for-hire.

- 36 percent of gas station workers.

- 26 percent of workers in warehousing, distribution, and fulfillment (i.e., who handle customer orders for e-commerce businesses).

- 16 percent of the state's agricultural employees, almost 30 percent of workers in food and beverage manufacturing and processing, and 32 percent in grocery and other food and beverage stores.

Appendix A provides CMS's estimates of undocumented immigrants, legal non-citizens, and naturalized citizens in New York State who work in essential businesses. For a detailed explanation of the methodology used to produce these estimates, see below. The 10 essential industries that employ the highest numbers of naturalized citizens include hospitals $(118,200$ workers), transportation infrastructure $(100,500)$, restaurants $(88,600)$, construction $(68,700)$, home health care $(61,200)$, banks $(51,800)$, building cleaners or janitors $(51,400)$, nursing homes $(41,500)$, government $(35,900)$, and services to individuals and families $(35,500)$. While some restaurants and construction sites continue to operate on a limited basis, it is difficult to estimate the precise number of immigrants who continue to work in these sectors.

Undocumented immigrants work - by essential industry - in restaurants (74,700 workers), construction $(72,500)$, home health care or as aides for the elderly $(19,800)$, building cleaners $(19,800)$, transportation infrastructure $(18,500)$, grocery stores including all food and beverage stores $(18,400)$, hospitals $(11,200)$, child care services $(7,600)$, landscapers $(7,400)$, and services related to financial markets $(7,200)$.

\section{Profiles of Essential Workers during the Pandemic}

CMS interviewed several immigrant essential workers who reside in New York State. Ismael Castellanos is a Mexican immigrant and has worked at a dairy farm in Batavia, New York for the last seven years. He helps to support his mother and siblings in his native country. His job entails taking care of calves - feeding them, bringing them to health, and ensuring their well-being - from the moment they are born until they are two months old. He performs this job outdoors, often in inclement weather that ranges from sub-zero temperatures to the summer heat. When he started to work at the farm, Ismael worked between 72 and 84 hours per week. Due to reformed New York State labor laws (New York State Department of Labor 2020), Ismael now works between 60 and 72 hours per week. He lives in employer-provided housing with four of his co-workers. Ismael says, "if we get sick, the entire farm will get sick." According to Ismael, his employer understands the symbiotic relationship between his farm and his workers where "if the workers get sick, the farm won't be able to operate, and if the farm stops producing, the workers will lose their jobs." His employer provides masks, disinfecting gel, and transportation to buy groceries.

2 This sector also includes cosmetic products. 
However, Ismael knows that owners of other ranches are not providing farmworkers with any protection or information about the virus.

Farmworkers like Ismael pay taxes, work hard, contribute to the economy, and help to maintain the nation's food supply. Yet many of these workers live in a vulnerable state due to their lack of mobility, isolation, and lack of access to healthcare. At the beginning of the pandemic when people were running to the supermarkets to stock up on food and goods, Ismael became disheartened to find empty shelves. In addition, he mentioned that the only nearby health clinic that catered to immigrant farmworkers had closed. The possibility of immigration enforcement also contributes to farmworkers' vulnerability. Ismael is a member of Alianza Agricola, a farmworker-led organization in Western and Central New York that has noticed more Immigration and Customs Enforcement (ICE) activity in Batavia since the pandemic started.

Janio Alvarado, an Ecuadorian immigrant who lives in the Bronx, manages a dental office in Washington Heights. Part of his job entails medical billing. Most of the office's patients are lowincome workers, and several receive Medicaid. To slow the spread of COVID-19, his office stopped providing non-emergency services such as routine cleanings. On a normal day, the office would receive 20-30 patients, but now they typically see only one to three patients who require emergency procedures. Despite the decreased business activity, Janio's employer, who is also an immigrant, sees value in keeping the office open. Janio stated, "patients who have dental emergencies may end up going to the hospital, which might increase their chance of COVID contraction." Given the lower number of patients, Janio's work hours have been reduced. He does not know how much longer the office will remain open. Unfortunately, government loan programs have not mitigated small businesses' need for assistance. The US Small Business Administration announced on April 16 that its Payroll Protection Program, which was designed to provide $\$ 350$ billion to small businesses to retain their staff, had run out of funds (Chang 2020). On April 21, the White House and Congress agreed to appropriate an additional $\$ 310$ billion to the program given the large demand for assistance (Pramuk 2020). Janio reports that his workplace is taking precautions, such as providing personal protection equipment and staggering patients to avoid overcrowding. However, when he recently tried to order masks, he learned that they are reserved for hospitals. He is worried about what will happen when their supply runs out.

Sara M. arrived in New York 28 years ago from Mexico. 3 She works as a clinical laboratory scientist at a cancer treatment center in Manhattan. Her job is considered essential, as laboratory tests have to be monitored 24 hours a day to ensure accuracy and specificity. Back in March, based on information shared by the World Health Organization (2020), Sara's employer suggested that it was not necessary for employees to wear masks unless they felt sick. Given that New York City was close to running out of protective wear, the laboratory prioritized the use of personal protective equipment for those who directly interact with patients. Sara and her coworkers created a bleach solution for sanitization. Her manager also started scheduling employees in 12-hour shifts to maintain social distance while working. After receiving a donation of masks, Sara and her co-workers have received one mask per day. Sara is also a DACA recipient. The uncertainty that comes from her status gave her a sense of what living in a

3 Sara preferred not to provide her full name to protect her identity. 
pandemic might be like. "I was already experiencing uncertainty before the pandemic started," she says. "So now I am just waiting it out. I'm just taking it one day at a time."

With New York and much of the country in lockdown, immigrant workers are sustaining the economy and helping to keep Americans healthy and safe. As Ismael puts it, "there are people who are able to stay safely at home, earning $\$ 40,000, \$ 50,000$ a year, have a good job, own a house. They are calm, but they do not know who is working day and night to ensure that food is available in their supermarkets and grocery stores ... we are the ones producing the food that arrives at their table."

\section{Methodology}

To arrive at these estimates, CMS used the essential business categories set forth in New York State's Executive Order 202 and clarified by state guidelines published on April 9 (New York State 2020). CMS matched each business category defined by New York State as essential with a 2017 industry code by the Census Bureau. In the few cases where New York essential business categories do not correspond to Census Bureau industry codes, CMS matched categories to 2018 Census Bureau occupational codes.4 CMS then calculated the number of workers in each essential sector using 2018 1-Year data from the American Community Survey data (IPUMS), weighted using individual weights calculated by the Census Bureau (Ruggles et al. 2020). CMS restricted the universe of employees to all individuals aged 16 and over.

Industry codes reflect the industries in which respondents to the American Community Survey (ACS) most recently performed their occupation. Likewise, occupation codes reflect individuals' most recent occupation. To restrict its estimates to individuals that were likely to be working in 2018, CMS's estimates include only individuals that were in the labor force at the time they responded to the ACS. Some individuals may work in more than one industry or occupation. For such individuals, the ACS records the industry or occupation in which they earned the most money.

Some industries (construction, restaurants, and hotels, for example) also may include high numbers of workers that are not working during the pandemic despite being categorized as working for essential businesses. Some workers may be furloughed or may have lost their jobs since 2018. These estimates thus should be regarded as an upper bound on the number of workers in essential businesses by their immigration status in New York State as of 2018.

CMS used both industry and occupational codes from the ACS to derive its estimates. Since industry codes encompass many occupations, CMS corrected its estimates for double count.

To estimate the number of naturalized citizens, legal non-citizens, and undocumented immigrants, CMS used information collected in the ACS. The annual series of CMS estimates of undocumented residents include all the detailed characteristics collected in the ACS (Ruggles et

4 These categories of essential businesses include corrections, electricians, plumbers, law enforcement, fire prevention and response, building inspection and code enforcement, security, emergency

management and response, building cleaners and janitors, disinfection, and logistics. 
al. 2020). A description of the CMS estimation procedures, as well as a discussion of the plausibility of the estimates, is provided in Warren (2020).

\section{References}

Chang, Sophia. "New York's Small Businesses Out of Luck As Federal, City Aid Dry Up." Gothamist, April 17, 2020. https://gothamist.com/news/new-yorks-small-businesses-outluck-federal-city-aid-dry. Accessed April 20, 2020.

New York State Department of Labor. 2020. "Minimum Wage Standards for Farm Workers." Albany, New York. https://labor.ny.gov/workerprotection/laborstandards/farm_labor.shtm

New York State, Empire State Development. 2020. "Guidance for Determining Whether a Business Enterprise is Subject to a Workforce Reduction under Recent Executive Orders." Albany, New York. https://esd.ny.gov/guidance-executive-order-2026

Pramuk, Jacob. "Senate passes $\$ 484$ billion coronavirus bill for small business and hospital relief, testing." CNBC, April 21, 2020. https://www.cnbc.com/2020/04/21/coronavirus-senatepasses-484-billion-small-business-relief-bill.html. Accessed April 23, 2020.

Steven Ruggles, Sarah Flood, Ronald Goeken, Josiah Grover, Erin Meyer, Jose Pacas and Matthew Sobek. IPUMS USA: Version 10.0 [dataset]. Minneapolis, MN: IPUMS, 2020. https://doi.org/10.18128/D010.V10.0

Warren, Robert. 2020. "Reverse Migration to Mexico Led to US Undocumented Population Decline: 2010 to 2018." Journal on Migration and Human Security 8:1, pp. 3241. https://doi.org/10.1177/2331502420906125

World Health Organization. 2020. "Coronavirus disease (COVID-19) advice for the public: When and how to use masks." https://www.who.int/emergencies/diseases/novel-coronavirus2019/advice-for-public/when-and-how-to-use-masks 


\section{Appendix}

\begin{tabular}{|c|c|c|c|c|c|}
\hline \multicolumn{6}{|c|}{ New York State } \\
\hline & $\begin{array}{l}\text { Naturalized } \\
\text { Immigrants }\end{array}$ & $\begin{array}{l}\text { Legal Non- } \\
\text { Citizens }\end{array}$ & Undocumented & $\begin{array}{l}\text { Total } \\
\text { Foreign } \\
\text { Born } 5\end{array}$ & $\begin{array}{l}\text { Immigrant Share of All Essential } \\
\text { Workers (Percent) }\end{array}$ \\
\hline Total & $1,035,700$ & 458,400 & 342,100 & $1,836,200$ & 31.5 \\
\hline $\begin{array}{l}\text { 1. Health Care } \\
\text { Operations }\end{array}$ & 277,900 & 87,900 & 43,200 & 409,000 & 32.9 \\
\hline Hospitals & 118,200 & 22,900 & 11,200 & 152,200 & 31.5 \\
\hline $\begin{array}{l}\text { Home Health Care } \\
\text { Workers or Aides } \\
\text { for the Elderly }\end{array}$ & 61,200 & 38,500 & 19,800 & 119,500 & 66.3 \\
\hline $\begin{array}{l}\text { Nursing homes or } \\
\text { residential health } \\
\text { care facilities or } \\
\text { congregate care } \\
\text { facilities }\end{array}$ & 41,500 & 11,800 & 3,300 & 56,700 & 29.4 \\
\hline $\begin{array}{l}\text { Offices of Doctors } \\
\text { and Dentists }\end{array}$ & 29,100 & 6,200 & 3,300 & 38,600 & 22.6 \\
\hline $\begin{array}{l}\text { Outpatient Health } \\
\text { Facilities }\end{array}$ & 12,500 & 3,300 & 3,300 & 19,100 & 21.6 \\
\hline All Other & 15,300 & 5,300 & 2,300 & 22,900 & 18.1 \\
\hline 2. Infrastructure & 139,000 & 53,800 & 26,200 & 219,000 & 39.4 \\
\hline $\begin{array}{l}\text { Transportation } \\
\text { Infrastructure such } \\
\text { as Bus, Rail, or For- } \\
\text { Hire Vehicles, } \\
\text { Garages }\end{array}$ & 100,500 & 40,200 & 18,500 & 159,200 & 47.1 \\
\hline $\begin{array}{l}\text { Hotels and Places } \\
\text { of Accommodation }\end{array}$ & 21,900 & 8,300 & 4,500 & 34,700 & 43.2 \\
\hline All Other & 16,600 & 5,200 & 3,200 & 25,100 & 18.3 \\
\hline 3. Manufacturing & 32,500 & 16,400 & 15,000 & 63,800 & 23.2 \\
\hline
\end{tabular}

${ }_{5}$ This column reflects the sums of unrounded totals, rounded to the nearest hundred. 


\begin{tabular}{|c|c|c|c|c|c|}
\hline $\begin{array}{l}\text { Food Processing, } \\
\text { Manufacturing } \\
\text { Agents, Including } \\
\text { All Foods and } \\
\text { Beverages }\end{array}$ & 10,200 & 5,900 & 5,900 & 21,900 & 29.6 \\
\hline $\begin{array}{l}\text { Microelectronics, } \\
\text { Semi-Conductors }\end{array}$ & 6,500 & 2,300 & 1,900 & 10,700 & 23.4 \\
\hline Pharmaceuticals & 5,700 & 2,600 & 800 & 9,100 & 30.5 \\
\hline $\begin{array}{l}\text { Agriculture and } \\
\text { Farms }\end{array}$ & 1,500 & 1,300 & 3,700 & 6,500 & 15.6 \\
\hline All Other & 8,600 & 4,300 & 2,800 & 15,700 & 18.7 \\
\hline 4. Retail & 138,000 & 92,800 & 98,900 & 329,700 & 35.2 \\
\hline Restaurants & 88,600 & 64,900 & 74,700 & 228,200 & 39.4 \\
\hline $\begin{array}{l}\text { Grocery Stores } \\
\text { including All Food } \\
\text { and Beverage } \\
\text { Stores }\end{array}$ & 24,400 & 20,200 & 18,400 & 63,100 & 31.9 \\
\hline Pharmacies & 11,900 & 3,200 & 2,900 & 18,000 & 27.2 \\
\hline All Other & 13,000 & 4,600 & 2,800 & 20,400 & 21.9 \\
\hline 5. Services & 80,200 & 36,200 & 31,800 & 148,200 & 31.1 \\
\hline Child Care Services & 27,400 & 14,300 & 7,600 & 49,300 & 38.3 \\
\hline $\begin{array}{l}\text { Mail and Shipping } \\
\text { Services }\end{array}$ & 19,600 & 3,700 & 2,700 & 25,900 & 27.2 \\
\hline Auto Repair & 8,700 & 5,900 & 4,300 & 18,900 & 26.6 \\
\hline Landscapers & 5,400 & 3,800 & 7,400 & 16,600 & 35.5 \\
\hline $\begin{array}{l}\text { Warehouse, } \\
\text { Distribution, and } \\
\text { Fulfillment }\end{array}$ & 7,700 & 4,000 & 2,300 & 14,000 & 26.5 \\
\hline Laundromats & 5,100 & 2,100 & 4,400 & 11,700 & 54.5 \\
\hline All Other & 6,400 & 2,400 & 3,000 & 11,800 & 19.6 \\
\hline $\begin{array}{l}\text { 6. Financial } \\
\text { Institutions }\end{array}$ & 107,100 & 40,500 & 14,100 & 161,700 & 25.2 \\
\hline Banks & 51,800 & 17,600 & 5,100 & 74,500 & 29.6 \\
\hline
\end{tabular}




\begin{tabular}{|c|c|c|c|c|c|}
\hline $\begin{array}{l}\text { Services Related to } \\
\text { Financial Markets }\end{array}$ & 25,400 & 12,500 & 7,200 & 45,100 & 25.0 \\
\hline All Other & 29,800 & 10,400 & 1,800 & 42,000 & 20.2 \\
\hline $\begin{array}{l}\text { 7. Providers of } \\
\text { Basic Necessities } \\
\text { to Economically } \\
\text { Disadvantaged } \\
\text { Populations and } \\
\text { Employees at } \\
\text { Correctional } \\
\text { Facilities }\end{array}$ & 42,100 & 18,500 & 6,300 & 66,900 & 28.8 \\
\hline $\begin{array}{l}\text { Services to } \\
\text { Individuals and } \\
\text { Families }\end{array}$ & 35,500 & 16,400 & 6,000 & 57,900 & 32.6 \\
\hline All Other & 6,600 & 2,100 & 300 & 9,000 & 16.4 \\
\hline 8. Construction & 81,600 & 56,000 & 77,200 & 214,800 & 36.7 \\
\hline Construction & 68,700 & 52,100 & 72,500 & 193,300 & 38.6 \\
\hline Electricians & 9,000 & 2,200 & 2,400 & 13,600 & 26.1 \\
\hline Plumbers & 3,900 & 1,800 & 2,300 & 8,000 & 25.0 \\
\hline $\begin{array}{l}\text { 9. Essential } \\
\text { Services Necessary } \\
\text { to Maintain the } \\
\text { Safety, Sanitation, } \\
\text { and Essential } \\
\text { Operations of } \\
\text { Residences or } \\
\text { Other Essential } \\
\text { Businesses, } \\
\text { Including: }\end{array}$ & 86,100 & 39,400 & 26,900 & 152,400 & 30.6 \\
\hline $\begin{array}{l}\text { Building Cleaners } \\
\text { or Janitors }\end{array}$ & 51,400 & 29,100 & 19,800 & 100,300 & 40.8 \\
\hline Security & 17,900 & 4,800 & 4,000 & 26,800 & 29.3 \\
\hline Law Enforcement ${ }^{6}$ & 10,800 & 2,000 & 0 & 12,700 & 13.3 \\
\hline Disinfection & 2,800 & 2,300 & 2,400 & 7,500 & 32.7 \\
\hline All Other & 3,300 & 1,100 & 700 & 5,100 & 12.2 \\
\hline
\end{tabular}

6 This industry includes private investigators. 


\begin{tabular}{|l|c|c|c|c|c|} 
& & & & \\
\hline $\begin{array}{l}\text { In. All Other } \\
\text { Industries, } \\
\text { Including the } \\
\begin{array}{l}\text { Public Sector and } \\
\text { Public Recreation } \\
\text { Areas }\end{array}\end{array}$ & 51,300 & 16,900 & 2,500 & 70,700 & 18.1 \\
\hline
\end{tabular}

Source: Center for Migration Studies. CMS estimates based on the 2018 1-Year American Community Survey data published through the Census Bureau. 